\title{
MODEL COMMUNICATION ENGGAGEMENT DALAM KOMUNIKASI POLITIK CALON LEGISLATIF DALAM PEMILU UMUM 2014
}

\author{
Zen Amirudin \\ Dosen Prodi Komunikasi FISIP Universitas Muhammadiyah Malang \\ zein_resist@yahoo.com
}

\begin{abstract}
Partai Kebangkitan Bangsa (PKB) Blitar in the general elections in 2014 gained nine seats compare to seven seats at previous election. The success caused due to synergistic communication engagements between political parties supporters such as Nahdlatul Ulama, Muslimat, Ansor Youth Movement and others. Meanwhile, during the campaign period, political communication of PKB Blitar candicate focus on: image building of candicate, campaign process, and communication media.
\end{abstract}

\begin{abstract}
Abstrak
Partai Kebangkitan Bangsa di Kabupaten Blitar dalam pemilihan umum 2014 telah berhasil memperoleh g kursi. Jumlah tersebut meningkat lebih banyakjika di bandingkan periode sebelumnya yang mendapatkan tujuh kursi. Faktor utama peningkatan kursi karena mampu menjalin komunikasi politik sinergis yang berbasis communication engagement antara aparatus partai politik, organisasi kemasyarakatan seperti Nahdlatul Ulama, Muslimat, Gerakan Pemuda Ansor maupun yang lainnya. Sedangkan proses komunikasi politik yang dilakukan oleh para calon legislatif PKB Kabupaten Blitar dalam melakukan kampanye dengan memfokuskan pada tiga hal utama, yakni: citra calon legislatif, proses kampanye, dan penggunaan media komunikasi.
\end{abstract}

Keywords: Political Communication, General Election, Communication Media

\section{PENDAHULUAN}

\section{Latar Belakang}

Partai politik melakukan fungsi-fungsi partai politik, salah satunya komunikasi politik. Komunikasi politik merupakan penyampaian informasi yang ada di partai politik terhadap masyarakat luas dan anggota partai politik sendiri. Komunikasi politik dipengaruhi oleh unsur-unsur yang ada dalam komunikasi politik, yaitu: sumber, pesan, saluran, umpan balik dan audiens atau pendengar (Rush dan Allthof, 1995: 225).

Sebuah sistem harus berjalan dengan baik dan saling mendukung agar isi pesan tersampaikan sesuai dengan apa yang diharapkan. Namun dalam pelaksanaannya, komunikasi politik seringkali mengalami permasalahan. Pelaksanaan fungsi komunikasi politik membutuhkan saluran yang tepat agar tidak terjadi miskomunikasi. Saluran ini bisa berupa media elektronik maupun cetak. Saluran komunikasi politik ini meru- 
pakan sarana penghubung antara komunikator dan komunikan. Agar komunikasi politik berjalan sesuai dengan apa yang diharapkan perlu adanya kesatuan dan hubungan yang baik antara orang-orang yang ada di partai politik tersebut. Komunikasi politik tidak dapat dilakukan secara intern saja tetapi juga ekstern.

Komunikasi politik ialah proses penyampaian informasi mengenai politik dari pemerintah kepada masyarakat dan dari masyarakat kepada pemerintah (Ramlan Surbakti, 1992: 199). Fungsi komunikasi politik tersebut dilakukan oleh semua anggota partai politik sebagai partisipan aktif di partai politik dan juga komunikator dalam menyampaikan isi informasi atau pesan. Di sini mereka sebagai komunikator harus dapat menyampaikan informasi tersebut secara tepat terhadap audiens atau pendengar, sehingga tidak terjadi miskomunikasi dari atas ke bawah.

Praktik komunikasi politik selalu mengikuti sistem politik yang berlaku. Di negara yang menganut sistem politik tertutup, komunikasi politik pada umumnya mengalir dari atas (penguasa) ke bawah (rakyat). Komunikasi politik semacam itu menerapkan paradigma komunikasi top down. Penerapan pendekatan ini memang bukan satu-satunya, namun yang dominan dilaksanakan adalah pendekatan top down. Untuk mewujudkan paradigma tersebut, pendekatan komunikasi politik terhadap media massa bersifat transmisional. Komunikasi politik semacam ini banyak dipraktikkan para penguasa ketika Indonesia menganut sistem politik tertutup.

Perubahan sistem politik ini idealnya mengubah pendekatan komunikasi politik dari satu arah menjadi banyak arah. Pada suatu saat menggunakan pendekatan top down, pada saat lain menerapkan pendekatan bottom up, dan pada kesempatan lain memperagakan paradigma horizontal. Pendekatan mana yang digunakan tergantung siapa yang menyampaikan pesan politik dan kepada siapa pesan itu ditujukan. Muatan pesan juga menentukan paradigma komunikasi mana yang digunakan.
Penerapan pendekatan itu tidak lagi menganggap penerima pesan politik sebagai sosok pasif yang "menelan" begitu saja pesan politik yang diterimanya. Pada Era Reformasi dengan sistem politik terbuka, penerima pesan politik dianggap aktif dan selektif. Pihak penerima mencerna dan menafsirkan pesan politikyang diterimanya sebagai proses sosial yang berkesinambungan.

Strategi komunikasi politik yang dibangun oleh calon legislatif (caleg) akan menjadi penting untuk kesuksesan pemilu. Bentuk dan media komunikasi politik menjadi cara dalam mendapatkan partisipan atau dukungan dari daerah pemilihan (Dapil) di Kabupaten Blitar. Karena dengan cara demikian pesan mereka bisa tersampaikan kepada masyarakat dan masyarakat bisa mengetahui siapa para caleg Kabupaten mereka yang akan menjadi pemimpin mereka dan sebagai pemimpin yang menjadi panutan, harapan dan untuk menjadi penyambung aspirasi rakyat di pemerintahan setidaknya 5 tahun mendatang.

\section{Partai Kebangkitan Bangsa (PKB)} Kabupaten Blitar merupakan salah satu partai yang selalu mendapatkan suara/kursi cukup signifikan. Hal tersebut dapat dilihat dari perolehan kursi sejak pemilu 1999 hingga 2009 yang selalu memperoleh lebih dari tujuh kursi. Bahkan bersasarkan dari laporan dan penetapan KPUD kabupaten Blitar, PKB mendapatkan sembilan (9) kursi dalam pemilu 2014. Hal tersebut mengalami kenaikan dari tahun 2009 yang memperoleh tujuh kursi.

Berdasarkan latar belakang masalah, maka untuk mempermudah arah dan pembahasan, peneliti membuat rumusan masalah sebagai berikut: Bagaimana Model Communication Engagement dalam Komunikasi Politik Calon Legislatif Terpilih pada Partai Kebangkitan Bangsa Kabupaten Blitar dalam Pemilihan Umum 2014? Dengan tujuan penelitian untuk melakukan telaah dan analisa terhadap salah satu fungsi partai politik, yakni model komunikasi politik yang dilakukan oleh Partai Kebangkitan Bangsa Kabupaten Blitar pada Pemilihan Umum 2014 berbasis communication engagement. 


\section{KAJIAN PUSTAKA}

\section{Hakekat Komunikasi Politik}

Komunikasi politik sebagai layaknya darah, mengalirkan pesan-pesan politik berupa tuntutan, protes, dan dukungan (aspirasi dan kepentingan) ke jantung (pusat) pemprosesan sistem politik dan hasil pemprosesan itu, yang tersimpul dalam fungsi-fungsi out put, dialirkan kembali oleh komunikasi politik yang selanjutnya menjadi feedback sistem politik (Alfian, 1993: 1). Begitulah, komunikasi politik menjadikan sistem politik itu hidup dan dinamis.

Dengan lain perkataan, komunikasi politik mempersambungkan semua bagian dari sistem politik, dan juga masa kini dengan masa lampau, sehingga dengan demikian aspirasi dan kepentingan dikonversikan menjadi berbagai kebijaksanaan. Bila mana komunikasi itu berjalan lancar, wajar, dan sehat maka sistem politik itu akan mencapai tingkatkualitasresponsifyangtinggiterhadap perkembangan aspirasi dan kepentingan masyarakat serta tuntutan, perubahan zaman. Lebih jauh Alfian menggambarkan peranan penting komunikasi politik dalam memelihara dan meningkatkan kualitas kehandalan suatu sistem politik yang sudah mapan. Komunikasi politik mentransmisikan nilai-nilai budaya politik yang bersumber dari pandangan hidup atau ideologi bersama masyarakatnya kepada generasi baru (anakanak, remaja, dan pemuda), dan memperkuat proses pembudayaannya dalam diri generasi yang lebih tua. (Alfian, 1993: 3-4).

Komunikasi politik adalah komunikasi yang melibatkan pesan-pesan politik, atau berkaitan dengan kekuasaan, pemerintahan, dan kebijakan pemerintah. Komunikasi politik tanpa aksi politik yang kongkret sebenarnya dilakukan oleh siapa saja: mahasiswa, dosen, tukang ojek, penjaga warung, dan seterusnya. Tak heran jika ada yang menjuluki komunikasi politik sebagai neologisme, yakni ilmu yang sebenarnya tak lebih dari istilah belaka. Secara praktis, komunikasi politik sangat kental dalam kehidupan sehari-hari karena manusia harus selalu berkomunikasi.
Nimmo (1993) mendefinisikan komunikasi politik sebagai kegiatan komunikasi yang mempertimbangkan politik berdasarkan konsekuensi-konsekuensinya (aktual maupun potensial) yang mengatur perbuatan manusia dalam kondisi konflik).

Sedangkan ahli politik yang lain mengatakan, bahwa komunikasi politik adalah komunikasi yang diarahkan kepada pencapaian suatu pengaruh sedemikian rupa, sehingga masalah yang dibahas oleh jenis kegiatan komunikasi tersebut dapat mengikat semua kelompok atau warganya, melalui suatu saksi yang ditentukan bersama oleh lembaga-lembaga politik. Sedangkan apabila dilihat dari tujuan politik an sich, maka hakikat komunikasi politik adalah upaya sekelompok manusia yang mempunyai orientasi, pemikiran politik atau ideologi tertentu dalam rangka menguasai, dan atau memperoleh kekuasaan demi mewujudkan tujuan pemikiran politik dan ideologi sebagaimana yang mereka harapkan (Harmoko dalam Maswadi Rauf dan Mappa Nasrun, 1993: 10).

Perkembangan komunikasi politik akan selalu mengikuti dan berimpit dengan kemajuan masyarakat. Semakin maju dan berkembang suatu masyarakat maka semakin kompleks pula problema yang dihadapi komunikasi. Kecepatan arus informasi atau komunikasi, tukar menukar fakta dan data visualisasi kemajaan suatu negara akan merupakan stimulasi bagi setiap negara untuk meningkatkan taraf kemajuannya. Untuk memberikan cakrawala pandangan tentang komunikasi politik secara totalitas, maka dalam tulisan ini akan dikemukakan beberapa pengertian tentang komunikasi dan politik serta fungsi komunikasi politik itu sendiri.

\section{METODE}

\section{Pendekatan dan Jenis Penelitian}

Penelitian dilaksanakan menggunakan jenispenelitiankualitatifdeskriptif.Penelitian ini bermaksud untuk melukiskan secara lengkap dan akurat tentang implementasi fungsi komunikasi politik PKB Kabupaten 
Blitar dalam pemilu 2014. Teknik analisis data dilakukan melalui beberpaa tahap: reduksi, verifikasi dan penyajian data (Sugiono, 2011: 246).

\section{HASIL DAN PEMBAHASAN}

\section{Mengembangkan Jaringan Komunikasi Para Caleg PKB}

Sebelum melakukan komunikasi ada dua tindakan yang dilakukan oleh para caleg PKB pada Pemilu 2014 yaitu mengembangkan jaringan komunikasi dan membuat pesan kampanye. Setelah penentuan nomor urut para caleg oleh masing-masing partai yang mengusungnya, tindakan yang dilakukan oleh caleg adalah menyusun strategi pemenangan. Hal ini pasti dilakukan bagi caleg yang ingin sukses dalam setiap Pemilu, tidak terkecuali caleg dari PKB yang masingmasing berjumlah 50 orang dan terbagi ke dalam lima daerah pemilihan atau dapil. Tim pemenangan yang dimaksud bertujuan untuk jaringan komunikasi politik baik pada tingkatpaling bawah(RT/dusun) hingga pada tingkat dapil dimana masing-masing dapil mencakup kurang lebih lima kecamatan.

Jaringan komunikasi dalam proses pemilihan Umum 2014 di Kabupaten Blitar yang dilakukanolehparacalegkhususnya PKB memiliki karakteristik yang berbeda-beda. Ada beberapa yang memanfaatkan jaringan komunikasi antar personal. Hal tersebut sabagaimana dilakukan oleh beberapa subyek berikut ini. Menurut Fatoni, yang merupakan salah satu caleg dari PKB dari Dapil V, jaringan komunikasi personal sudah dilakukan dalam kurun waktu yang lama. Hal tersebut disebabkan dia telah menjadi petahana dari partai Patriot, yang kemudian pindah ke PKB. Berikut ini penjelasannya lebih detail;

"Saya selalu sempatkan untuk sms atau kontak kader-kader saya mas. Itu sangat penting meskipun saya sapa hanya melalui sms atau telepon. Ternyata hasilnya sangat antusis. Selain itu komunikasi personal saya lakukan terutama dengan para colega deket saya seperti keluarga, famili dari mertua ataupun teman-teman sekolah yang ada di daerah pemilihan saya. Ya caranya sih gampang saja, kadang saya datang di acara ngopi, mancing, atau sekedar diskusi berdua”

Dalam kesempatan yang berbeda, caleg lain yang juga dari Dapil V yang bernama Ansori justru mengatakan berbeda soal jaringan komunikasi. Dia lebih menekankan pada upaya membuat jaringan formal terlebih dulu seperti koordinator tim sukses pada tingkat dapil, kemudian strukturnya hingga pada level ranting dan hingga TPS.

Dalam keadaan yang lain, subyek lain yang bernama Ririn H merupakan salah satu caleg perempuan yang lolos dalam pemilihan umum 2014. Berdasarkan pengalamannya, pada mulanya untuk dapat masuk ke daerah-daerah NU saja sulit karena sudah banyak kecurigaan dan sentimen politik dari masyarakat disekitarnya. Sebagai pendatang baru di kancah politik, masuk PKB membawa berkah untuknya. Diakui Ririn selama ini ia memiliki sedikit teman di Blitar, sekarang dengan ikut pemilu ia jadi terkenal, minimal di dapil II. Pengalamannya membuat jaringan komunikasi diceritakan sebagai berikut ini.

"Pertama saya menemui pimpinan NU dan pimpinan Muslimat mas, karena di daerah saya hal tersebut sangat vital untuk bisa meraup dukungan politik. Mustahil saya dapat suara yang membuat saya lolos ke DPRD kalau saya tidak bisa masuk di "ruang" itu mas. Mereka saya dekati secara pesuasif, saya libatkan dalam pendulangan suara saya, saya rekrut jadi tim sukses saya, bahkan dalam beberapa kebutuhan saya fasilitasi seperti kasih pulsa untuk komunikasi, uang tranport dan rokok dan beberapa yang lain. Selain itu juga saya membangun komunikasi dengan kelompok tani, kelompok karang taruna dan siapapun yang mau kerja sama dengan saya"

Jaringan komunikasi sangat penting dibentuk dalam rangka untuk melakukan komunikasi dan mensosialisasikan berbagai program serta lebih jauh mengenalkan profil masing-masing caleg. sebagaimana 
dijelaskan oleh salah satu caleg dan sekaligus ketua PKB Kabupaten Blitar berikut ini.

"Hal penting seorang politisi ketika menjadicaleg tentunyaadalah memiliki jaringan luas serta komunikasi yang bagus. Kalau tidak jangan berharap bisa mendapatkan suara banyak. Tentu jaringan yang dimaksud itu adalah membuat dan mengumpulkan semua keluarga, sahabat, tetangga, tokoh masyarakat, tokoh agama, struktural politisi dan atau siapapun. Intinya dalam keadaan seperti itu semua adalah sahabat, semua adalah keluarga, karena kita ini memperoleh dukungannya, iya nggak?"

Dengan melihat pernyataan tersebut, jaringan komunikasi sangatlah penting dalam menopang keberhasilan caleg. Jaringan dapat dibentuk melalui kelompokkelompok sosial kemasyarakatan yang sudah ada maupun melalui kelompok keagamaan seperti Muslimat, Fatayat, Anshor maupun jaringan NU sendiri.

Sementara itu caleg lain, salah satu pimpinan PKB Blitar, Nur Fathoni telah periode kedua sebagai anggota DPRD.

"Jaringan yang telah saya buat, saya rawat, bahkan terus dikembangkan sesuai dengan kebutuhan yang ada. Dia tau politik, jadi saya sudah antisipasi dari awal soal jaringan komunikasi. Memang sih ada beberapa yang pindah ke caleg yang lain, tapi akhirnya juga kembali ke saya lagi, gak tau apa alasannya."

Menurut penjelasan di atas pengembangan jaringan politik termasuk dalam kegiatan simbolik yang berupa katakata dalam pembicaraan politik. Kegiatan simbolik terdiri atas orang-orang yang menyusun makna dan tanggapan bersama terhadap perwujudan lambang-lambang referensial dan kondensasi dalam bentuk kata-kata, gambar, dan perilaku. Dengan mengatakan bahwa makna dan tanggapan itu berasal dari pengambilan peran bersama, kita meminta perhatian kepada orang untuk memainkan peran. Hal ini berlaku baik bagi lambang politik maupun bagi lambang jenis apapun.

\section{Teknik Membuat Pesan Kampanye Yang Strategis Para Caleg}

Kampanye merupakan bagian yang penting dalam proses Pemilu 2014 di Kabupaten Blitar. Bahkan menurut beberapa calon legislatif, beberapa bulan sebelum jadwal kampanye dikeluarkan oleh KPUD, banyak aktifitas yang dilakukan dalam rangka kampanye yang dikemas dalam tahapan sosialisasi. Kegiatan sosialisasi pada hakekatnya adalah kegiatan kampanye itu sendiri.

Menurut RH, salah satu caleg PKB Blitar yang sekarang menjadi salah salah anggota legislatif, kegiatan sosialisasi sangat menentukan untuk melakukan pemetaan politik. Dengan cara sosialisasi tersebut ada beberapa tujuan yang dapat diraih. Pertama, untuk mengetahui keinginan masyarakat (pemilih). Kedua, untuk memahami peta politik "lawan/rival". Ketiga, agar masyarakat mengetahui profil dan visi misi dari caleg itu sendiri.

Caleg lain, AS, berpendapat masa prakampanye adalaha masa mengenalkan diri kepada calon pemilih. Bagi AS Pemilu 2014 adalah periode keduanya dalam pemilihannya tidak terlalu sulit untuk melakukan pemetaan politik kepada calon pemilihnya di Dapil V.

Ada beberapa hal substansial yang penting dalam membuat pesan kampanye. Dalam berbagai kasus dan kejadian yang ada di beberapa daerah, pesan kampanye yang terlalu panjang akan membosankan, tetapi kalau tidak jelas maksudnya juga akan membuat bingung calon pemilih. Berikut ini adalah beberapa hasil wawancara dari para caleg baik dari PKB Kabupaten Blitar dalam merumuskan pesan kampanye. Hal tersebut sabagaimana dijelaskan oleh salah satu subyek berikut ini.

"Jauh hari sebelum pemilu sudah menyusun pesan kampanye mas. Apalagi sebagai ketua partai, saya selalu 
berfikir supaya bagaimana agar PKB dapat terus diketahui masyarakat, dan akanmendapatkansuarayangsignifikan dalam pemilihan yang lalu. Tentu hal tersebut membutuhkan kemampuan dan upaya bagaimana supaya pesan kampanye bisa efektif. Kalau sebagai caleg sendiri saya memilih Dapil II, Dapil yang sebenarnya ukup berat. Tapi saya punya keyakinan bagaimana untuk mendapatkan dukungan semaksimal mungkin dan alhamdulillah saya hampir memenuhi BPP dalam pemilu 2014 lalu mas"

\section{Tahapan Pola Komunikasi Politik PKB dalam Pemilu 2014}

Setelah membangun jaringan dan merumukan pesan kampanye politik, para calegmenyusunlangkah-langkahkomunikasi politik: pemetaan politik, membuat target suara, mendesain dan membangun mesin suara, up-grading mesin suara, menjalankan program, evaluasi monitoring. Gambar 1 di bawah ini menjelaskan tujuh langkah sukses Pemilu 2014. Satu persatu tahapan akan dibahas berikut ini (lihat gambar 1).

\section{Melakukan Pemetaaan Politik.}

Pemetaan politik adalah melakukan analisis terhadap kekuatan dan kelemahan diri dan lawan, kondisi "medan pertempuran, "iklim" medan pertempuran dan media komunikasi. Ibarat seorang yang akan melakukan perjalanan, peta politik ini bisa menjadi panduan untuk mencapai tujuan dengan efektif dan efisien. Banyak kandidat telah sadar akan pentingnya pemetaan politik. Pemetaan politik yang paling akurat adalah dengan melakukan survei. Dengan melakukan survei, kandidat dapat mengumpulkan berbagai informasi sangat penting dan akurat.

Kemenangan caleg PKB ditentukan oleh strategi pemenangan yang diterapkan oleh kandidat. Strategi ini lah yang sesungguhnya menentukan seorang kandidat menang atau kalah dalam sebuah Pemilu. Strategi yang dimaksud di sini adalah bagaimana cara atau jurus seorang kandidat dalam mengalahkan lawan-lawannya. Kandidat bisa menggunakan jurus David Carradine dalam film Kung Fu: The Legend Continues yang mengalahkan lawan-lawannya dengan jurus yang efektif dan memanfaatkan tenaga lawan.

Petapolitikadalahseperangkat informasi yang valid yang menggambarkan secara jelas menyangkut kandidat sendiri, pesaing, masyarakat (pemilih), media komunikasi, dan berbagai isu strategis. Peta politik ini sangat penting dimiliki oleh setiap kandidat. Peta politik ini akan menuntun kandidat untuk menentukan jalan yang paling efektif dan efsien untuk mencapai tujuan. Ibarat seseorang yang akan menuju suatu tempat, bila ia membawa peta kandidat tidak akan tersesat di jalan dan bahkan bisa menentukan jalan mana dan kendaraan apa yang akan ia gunakan untuk mencapai tujuan secara cepat dan efisien. Dengan peta politik ini kandidat

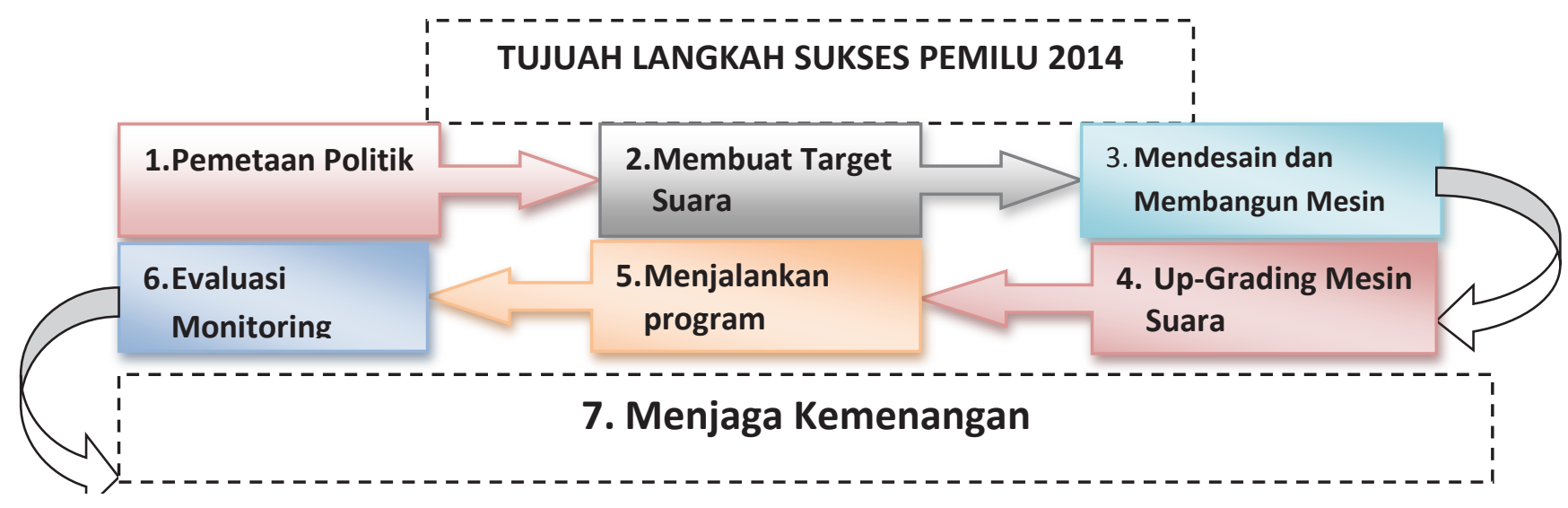

Gambar 1. Tujuh Langkah Sukses Pemilu 2014 
juga akan mengetahui berbagai kelemahan dan kekuatan diri sendiri dan pesaingnya.

\section{Membuat Target Suara}

Realitas politik menunjukkan bahwa Kabupaten Blitar masih dikuasai oleh kaum Nadhliyin (NU; PKB). Dengan afiliasi yang dimiliki caleg PKB dan komitmennya untuk selalu dekat dengan NU selama ini maka menjadi modal politik yang strategis untuk mendesain ulang jaringan yang ada. Adapun jaringan tersebut dapat dilakukan dengan optimalisasi kerjasama dengan beberapa lembaga/organisasi sayap yang dimiliki NU seperti organisasi NU, Muslimat, Fatayat, Ansor, Banser maupun PMII. Organisasi binaan NU tersebut jelas secara struktural memiliki ideologi yang mampu merekatkan konstituen di lapangan.

\section{Mendesain dan Membangun Mesin Suara}

Bila target suara sudah ditentukan, langkah selanjutnya adalah merumuskan cara mencapai target suara tersebut. Untuk bisa mencapai target suara tersebut, kandidat harus memiliki mesin suara yang dapat memobilisasi suara. Ada dua mesin suara yang harus dipahami oleh kandidat dan tim sukses yaitu Mesin Jaringan dan Mesin Pencitraan. Dalam Pemilu kabupaten/kota, porsi mesin jaringan sangat dominan, kirakira mencapai $75 \%$. Sedangkan di tingkat Propinsi, porsi mesin jaringan mencapai 50\% dan mesin pencitraan $50 \%$. Sementara itu untuk Pilpres, porsi mesin pencitraan lebih dominan mencapai $75 \%$ dan mesin jaringan hanya $25 \%$. Mesin jaringan yang sudah tersedia biasanya adalah jaringan partai politik. Selain di dalam partai, kandidat perlu perlu membuat jaringan di luar jaringan partai.

\section{Up-grade Mesin Suara}

Mesin jaringan yang paling efektif digunakan oleh kandidat adalah jaringan yang sudah eksis sebelumnya di masyarakat. Jaringan yang sudah eksis di masyarakat biasanya sudah memiliki jaringan yang luas dan mekanisme organisasi sudah berjalan. Namun bila kandidat tidak menemukan jaringan yang sudah eksis maka kandidat harus membuat atau menciptakannya.

Jaringan yang sudah terbentuk harus dibekali kemampuan untuk "menjual". Jaringan ini adalah ibarat para wiraniaga penjual produk. Mereka harus diberi target jumlah penjualan produk oleh karena mereka perlu dibekali dengan "ilmu" penjualan produk. Bila sebelumnya mereka hanya mampu menjual produk kepada satu orang, dengan kita lakukan pelatihan komunikasi politik mereka akan bisa menjual kepada 10 orang misalnya. Jaringan juga mesti kita rawat agar tidak dibajak oleh kandidat lain.

Selain jaringaan formal partai, maka juga akan mengoptimalkan jaringan non-formal kepartaian. Berbagai organisasi keagamaan, kemasyarakatan seperti halnya NU, Muhammadiyah, Birokrasi, LSM, kelompok pedagang dan lainnya mampu disinergikan dengan visi misi PKB. Peran mereka sangat memiliki arti signifikan dalam mendulang perolehan suara PKB dalam Pemilu 2014 yang lalu.

\section{Menjalankan Program}

Program PKB sebagaimanayang tertuang dalam lampiran tersendiri laporan ini (visi, misi dan Program PKB) merupakan sebuah perspektif pandang kepemimpinan PKB mendatang. Khsusus untuk pemenangan PKB, maka program pemenangan (sebagaiman dalam bab sebelumnya) harus mampu dijalankan secara optimal. Berbagai program baik dari mulai sosialisasi hingga tahap pemilihan harus mampu dijalankan dengan optimal. Memang dalam konteks pemenangan, PKB tidak harus menang mutlak diseluruh wilayah di Blitar, namun perlu 'daerah aman' yang selama ini dibangun perlu diberdayakan harus sesuai dengan target perolehan suara. Untuk mencapai itu, dilakukan program yang terukur dan terarah untuk proses pencitraan hingga eksekusi pemilihan pada o9 April 2014 yang lalu. 


\section{Evaluasi dan Monitoring}

Evaluasi merupakan langkah yang penting dalam proses pemenangan politik. Setiap program yang dijalankan harus terukur sesuai dengan tupoksi yang dijalankan oleh tim sukses PKB. Dalam hal ini monitoring dilakukan oleh ketua tim sukses pada masing-masing daerah untuk mengetahui kemajuan dalam kurun waktu 2 mingguan. Sehingga jika dipandang kurang bagus akan segera mampu dilakukan perbaikan.

\section{Menjaga Kemenangan}

Pada langkah terakhir ini menurut data di lapangan dan penjelasan beberapa informan ada faktor kunci untuk meraih kemenangan setelah proses panjang melalui tahapan sosialisasi hingga kampanye. Hari $\mathrm{H}$ merupakan penentuan kalah menang. Oleh sebab itu, PKB mengerahkan semua kekuatan yang dimilikinya dari ring I hingga ring IV (akar rumput; saksi di TPS, dan ataupun juga pemantau dari tim sukses). Hasil rekepitulasi akan sangat menentukan untuk mengetahui jumlah kemenangan dan juga hal lain diluar dugaan dari tim sukses sendiri. Tahapan menjaga kemenangan mampu dilakukan pada level TPS, KPUD kabupaten/Kota hingga propinsi, mengingat seringkali ada manipulasi atau kecurangan yang dilakukan dari pihak lain. Oleh sebab itu tim PKB selalu harus waspada dan menjaga kemenangan itu.

Strategi komunikasi politik suatu partai politik terhadap masyarakat umum sangat diperlukan dalam menghadapi sebuah pemilihan umum. Keberhasilan suatu strategi komunikasi politik oleh partai dalam merencanakan dan melaksanakan akan ikut berperan pada hasil perolehan suara partai politik dalam pemilu. Menurut Firmanzah (2008) strategi komunikasi politik sangat penting untuk dianalisis. Soalnya, strategi tersebut tidak hanya menentukan kemenangan politik pesaing, tetapi juga akan berpengaruh terhadap perolehan suara partai.

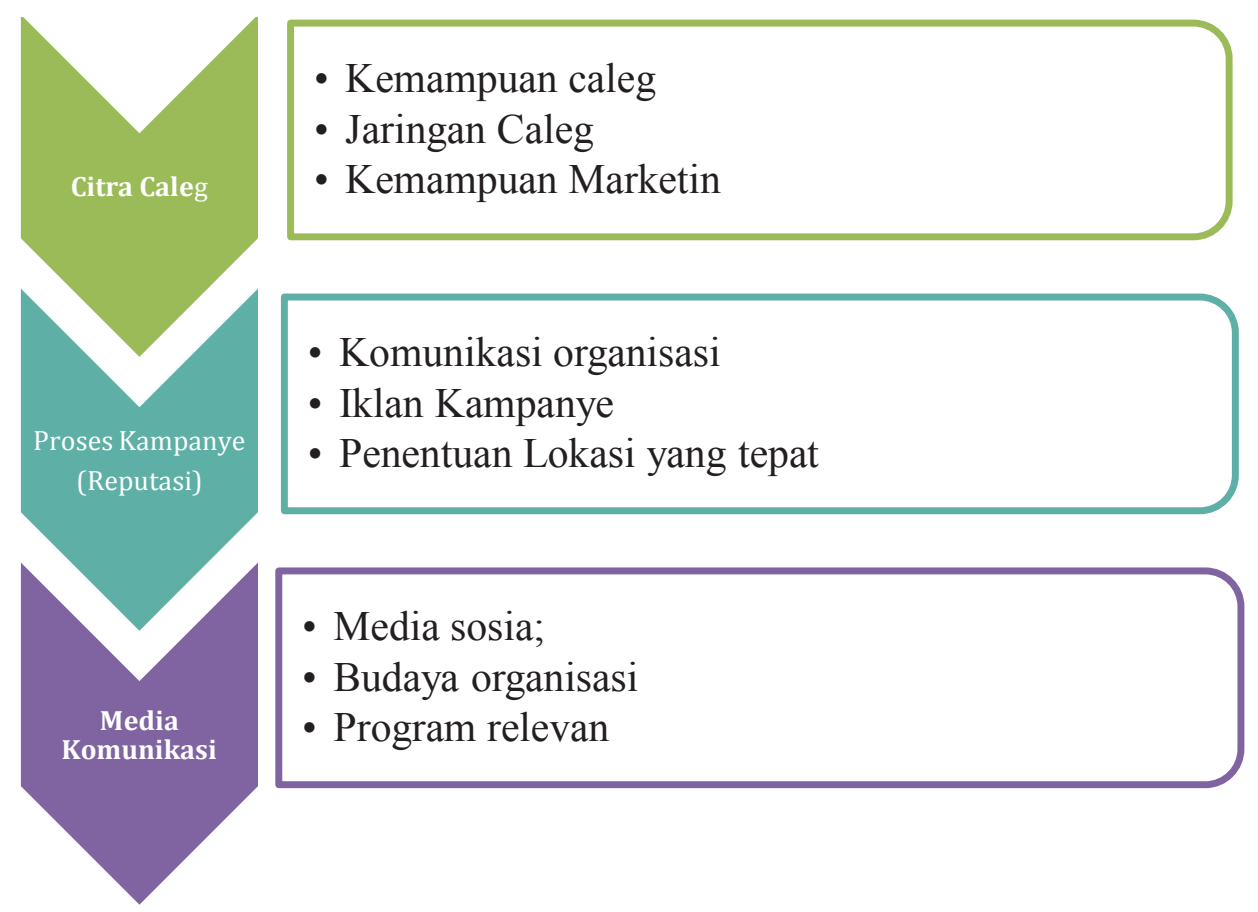

Gambar 2. Model Komunikasi Calon Legislatif berbasis

Communication Engagement

Sumber: data primer diolah 


\section{Model Communication Engagement dalam Pemilu 2014}

Komunikasi politik memerlukan berbagai strategi untuk tercapainya pesan yang efektif. Demikian juga dalam pemenangan PKB Blitar dalam Pemilu 2014 mampu diketahui beberapa strategi dan pola komunikasi para caleg. Adapun modelnya adalah sebagai berikut ini (lihat gambar 2).

Gambar tersebut menjelaskan tentang proses komunikasi yang pada umumnya dilakukan oleh para caleg PKB Kabupaten Blitar dalam melakukan komunikasi kampanye dalam pemilihan umum 2014 yang lalu. Ada tiga hal utama yang dapat dilihat dalam model tersebut: citra caleg, proses kampanye dan media komunikasi.

\section{SIMPULAN}

Komunikasi politik di Indonesia khususnya di Kabupaten Blitar menggunakan dua sistem komunikasi dominan, yaitu media massa modern dan sistem komunikasi tradisional (Schramm, 1964). Untuk mempengaruhi masyarakat, diperlukan sarana komunikasi yang tepat sesuai dengan keperluan dan tujuan pesan politik.

Model communication engagement yang dilakukan oleh caleg PKB Blitar dalam Pemilu 2014 terbagi menjadi tiga bagian yaitu: pembentukan jaringan, penyusunan pesan kampanye dan pelaksanaan komunikasi. Pada pelaksanaan komunikasi dibagi menjadi 7 tahap yaitu: pemetaan politik, membuat target suara, mendesain dan membangun mesin suara, up-grading mesin suara, menjalankan program, evaluasi monitoring. Ada tiga hal utama yang dapat dilihat dalam model communication engagement yaitu: citra caleg, proses kampanye dan media komunikasi.

\section{DAFTAR PUSTAKA}

Alfian. 1993. Komunikasi Politik dan Sistem Politik di Indonesia. Jakarta: Gramedia Pustaka Utama.

Allthof, Phillip. Michael Rush.1995. Pengantar Sosiologi Politik. Jakarta: Raja Grafindo

Firmasyah. 2008. Mengelola Partai Politik. Jakarta: Yayasan Obor Indonesia.

Nimmo, Dan. 1993. Komunikasi Politik, Komunikator, Pesan dan Media. Bandung: Remaja Rosdakarya.

Rauf, Maswadi dan Nasrun Mappa. 1993. Indonesia dan Komunikasi Politik. Jakarta: Gramedia Pustaka Utama.

Schramm, W. 1964. Mass Media and National Development: the Role of Information in the Developing Countries. Stanford California: Stanford University Press.

Sugiyono. 2011. Metode Penelitian Kuantitatif, Kualitatif dan R \& D. Bandung: Alfabeta

Surbakti, Ramlan. 1992. Memahami Ilmu Politik. Jakarta: Gramedia Pustaka Utama. 
